\title{
THE SURVEY OF SEA CUCUMBER FISHERIES ON QESHM ISLAND COASTS (PERSIAN GULF)
}

\author{
Majid AFKHAMI *, Maryam EHSANPOUR **, \\ Amin MOKHLECI *** and Kazem DARVISH BASTAMI*
}

* Islamic Azad University Central Tehran Branch, Yung Researchers Club, Tehran, Iran P. B. 15655/461,m_afkhami82@yahoo.com, aida.khazaali@yahoo.com,darvish_60@yahoo.com

** Islamic Azad University Central Tehran Branch, Young Researchers Club, Tehran, Iran, P. O. Box 15655/461,mehsanpour@yahoo.com

*** Islamic Azad University, Central Tehran Branch, Young Researchers Club, Tehran, Iran, P. O. Box 13185-768,aminmokhleci@gmail.com

KEYWORDS: sea cucumber, Holothuria scabra, fishing status, Qeshm Island, Persian Gulf.

\section{ABSTRACT}

Sea cucumbers are aquatic animals of wide variety, useful for human health. Sea cucumbers are among the aquatic creatures that have many important and useful properties known for human health. Increasing demand for beche-de-mer, along with steady price increases, has led to worldwide intensification of sea cucumber harvesting. The rearing of sea cucumbers with shrimps controls environmental pollution that results from over- enrichment in nutrients, built up on the pond bottom.

These animals eat detritus and, together with devouring organic materials on the surface, not only do they clean the environment, but also they cause the fast growth of shrimps and themselves. Holothuria scabra is the main species for production of beche-de-mer and is exploited especially in the tropical regions of the world. The wall of the body used in the process of beche-de-mer production forms $56 \%$ of the whole body. Holothuria scabra (sandfish) is an aspidochirote holothurian widely distributed in coastal regions throughout the Indo-Pacific region. H. scabra is often found on inner reef flats and near estuaries, half-buried in silty sand during the day and emerging at night to feed.

In this study, based on information from local fishermen on Qeshm Island, we provide some data about the fishing methods, processing and distribution on the Qeshm Island coastline. Comparative study of fishing status with another part of the world determined that the status of sea cucumber stocks in Qeshm Island is sustainable. For prevention of overexploitation of the sandy sea cucumber, prohibition on capturing should continue.

In this study, seven exploited sites are recognized, the target size for fishermen was more than $20 \mathrm{~cm}$ and sandy cucumber was the target species in Qeshm Island. In this area, the fishing operation was only carried out by scuba diving and was done only by men; although in another countries women have an important role in sea cucumber fishing activities. Among the coasts around Qeshm Island, it is found at Hmoon, Tolla, Kovei, Ramchah, Messen and Hengam. A maximum length of $35 \mathrm{~cm}$ and maximum weight of $1,080 \mathrm{~g}$ was recorded. 
RÉSUMÉ: L'étude de la pêche de concombres de mer sur les côtes de l'île de Qeshm (Golfe Persique).

Les concombres de mer sont des animaux aquatiques ayant une large utilisation dans la médicine naturaliste, avec les plus nombreuses et utiles applications comparé aux autres organismes aquatiques. La demande croissante pour la bêche de mer ainsi que l'augmentation constante des prix ont mené à une recrudescence au niveau global de la récolte des holothuries comestibles. Leur élevage avec des crevettes permet le maintien de la pollution de l'eau suite à la formation des dépôts benthiques riches en nutriments à des niveaux acceptables.

Ces animaux consomment des détritus et d'autres substances organiques déposées sur différentes surfaces, nettoyant ainsi le milieu et permettant une prise de poids plus rapide des crevettes. Holothuria scabra est la principale espèce de bêche de mer et également la plus exploitée dans les régions tropicales. La partie de la bêche de mer utilisée est obtenue à partir de la paroi de la cavité corporelle de ces animaux et représente jusqu'à $56 \%$ de la masse corporelle d'un individu. Holothuria scabra (sandfish) est une holothurie aspidochirote largement répandue dans les zones côtières de la région Indopacifique. Holothuria scabra vit notamment sur les fonds plats à l'intérieur des récifs ainsi qu'à la proximité des estuaires, partiellement enterrée dans la vase durant la journée et sortant pour se nourrir durant la nuit.

À la suite de l'étude effectuée à partir des informations obtenues des pêcheurs de l'île de Qeshm, nous présentons ici des données concernant les méthodes de pêche, préparation et distribution dans la zone côtière de l'île de Qeshm. L'étude compare le statut de ces animaux sur l'île de Qeshm avec les stocks disponibles dans d'autres régions du monde. L'interdiction de la cueillette est recommandée afin de prévenir la surpêche de cette espèce.

Dans cette étude sont répertoriées sept sites d'exploitation comportant pour chacun d'entre eux les données des pêcheurs de la côte de l'île de Qeshm capturant des animaux appartenant à l'espèce Holothuria scabra et ayant plus de $20 \mathrm{~cm}$ de long. Dans cette région, la pêche est pratiquée uniquement par les hommes, munies d'équipement de plongée. Néanmoins, il y a des pays où cette activité est pratiquée surtout par des femmes. Sur les côtes de l'île de Qeshm, Holothuria scabra est exploitée à Hmoon, Tolla, Kovei, Ramchah, Messen et Hengam. Le plus grand individu enregistré mesurait $35 \mathrm{~cm}$ de longueur pour une masse de $1.080 \mathrm{~g}$.

REZUMAT: Studiul pescăriilor de castraveți de mare de pe coastele insulei Qeshm (Golful Persic).

Castraveții de mare sunt animale acvatice cu o largă utilizare în medicina naturistă, având cele mai numeroase și utile aplicaţii dintre organismele acvatice. Creșterea din ce în ce mai mare a cererii pentru trepang precum și creșterea constantă a prețurilor au dus la o recrudescență la nivel mondial a recoltării castraveţilor de mare comestibili. Creșterea în regim de acvacultură a acestora împreună cu creveții permite menținerea sub control a poluării mediului cauzată de depunerea detritusului foarte bogat în nutrienţi.

Aceste animale consumă detritus și alte substanțe organice depuse pe diferite suprafețe submerse, curățând astfel mediul şi ducând la o creștere mai accelerată atât proprie cât şi a speciilor asociate în cultură. Holothuria scabra este principala specie de trepang și cea mai exploatată în regiunile tropicale ale lumii. Trepangul este peretele musculos al cavității corporale a holoturiilor comestibile și ajunge la aproximativ $56 \%$ din masa corporală a acestora. Holothuria scabra este o holoturie din ordinul Aspidochirota răspândită pe scară largă în zonele costiere ale regiunii Indo-Pacifice. Holothuria scabra se găsește cel mai adesea pe platourile nisipoase intrarecifale și în apropierea estuarelor, parțial îngropată în mâl pe timpul zilei și hrănindu-se activ pe timpul nopțiii. 
În urma studiului efectuat pe baza informațiilor obţinute de la pescarii de pe Insula Qeshm, furnizăm aici date cu privire la metodele de pescuit, procesare și distribuţie în zona costieră a insulei Qeshm. Se impune studiul comparativ al statutului piscicol al acestor animale în insula Qeshm cu cel al stocurilor existente în alte părți ale lumii. Prohibiția recoltării acestei specii este recomandabilă pentru a preveni supraexploatarea speciei.

În acest studiu, sunt recunoscute şapte situri de exploatare, pescarii recoltând animale din specia Holothuria scabra de minim $20 \mathrm{~cm}$ lungime în apele de coastă ale insulei Qeshm. În această zonă pescuitul se practică numai cu echipament de scufundare cu tuburi de oxigen și practicanții sunt exclusiv bărbați. $\mathrm{Cu}$ toate acestea, există țări unde femeile sunt cele ce se îndeletnicesc preponderent cu această ocupație. Specia este exploatată în apele de coastă ale insulei Qeshm în Hmoon, Tolla, Kovei, Ramchah, Messen și Hengam. Lungimea maximă înregistrată a fost de $35 \mathrm{~cm}$, iar greutatea maximă a fost de $1080 \mathrm{~g}$.

\section{INTRODUCTION}

No studies have been conducted on sea cucumber harvesting and management in Iran until now. The primary species harvested in Iran is the sandfish, Holothuria scabra (called "khiar daryaei" in the local language, which means "sea cucumber"). Although there are a growing number of studies focusing on echinoderms and holothurians worldwide, the Persian Gulf has not received much attention. There are no (to our knowledge) first hand records of sea cucumbers fisheries and stock assessment in this region.

Until now, 1,400 species of sea cucumber have been identified and reported in the seas around the whole world (Conand, 2006a). Sea cucumbers are aquatic creatures that have many important and useful properties known for human health (Mamelona et al., 2007). The wall of the body is used in the process of beche-de-mer production that forms $56 \%$ of the whole body. The amount of the sea cucumber protein is high and equivalent to $81.8 \%$ of the dry body weight (Alexander et al., 2005).

A lot of researches have been done on medicinal and therapeutic properties of different species (Murray et al., 2001). There are different types of toxic species among sea cucumbers. The fish called holothurians is used as an anti-cancer drug (Thomas et al., 1997). In addition, sea cucumber oils contain anti-inflammatory substances, which contain fatty acids. It is effective for reducing inflammations and strengthening the brain (Mamelona et al., 2007). The rearing of sea cucumber with shrimp controls the environmental pollution results from extra enriched nutritious built on the pond bottom. These animals eat detritus and devour organic materials on the surface, making the environment clean, and also causing the fast growth of shrimp and themselves (James, 2001).

Sandfish are usually observed partially buried in the water bottom sediments. The daily burrowing cycle varies according to environmental conditions. The growth rate of sandfish depends on environmental conditions and the time of year. At medium size, sand fish grow on average with $0.5 \mathrm{~cm}$ per month, corresponding to $14 \mathrm{~g}$ per month. Under favourable conditions they grow up to a size of $300 \mathrm{~g}$ in one year. We still do not know how long sandfish live, but it may be around 10 years. Sandfish can become sexually mature at a size of $200 \mathrm{~g}$. There is no apparent relationship between fecundity (egg production) and body size (FAO, 2006). 
The preferred habitats of sandfish are shallow tropical waters, usually less than $20 \mathrm{~m}$ deep, such as sheltered areas with high levels of nutrients, including muddy substrata and sea grass beds.

They can tolerate reduced salinity (20 ppt) for a short period and so are sometimes found in brackish water (FAO, 2006).

The sea cucumber Holothuria scabra versicolor (golden sandfish) is one of the most highly sought species in Asia. Holothuria scabra and Holothuria scabra versicolor are distributed throughout the tropical Indian and Western Pacific oceans area and their occurrence was noted from Madagascar to the Solomon Islands and New Caledonia (Conand, 1998a). Although Holothuria scabra and Holothuria scabra versicolor are both found over a large geographical range, they often inhabit dissimilar microhabitats, with Holothuria scabra versicolor, often found in deeper waters than Holothuria scabra (Conand, 1990).

The sea cucumber Holothuria scabra, yield one of the largest sea cucumber catches worldwide (Brookes and Shannon, 2004).

Increasing demand for beche-de-mer along with steady price increases has led to worldwide intensification of sea cucumber harvesting (Conand, 2004). The worldwide supply of high quality beche-de-mer would not be sufficient to satisfy the Asian market demand, unless a viable sea cucumber aquaculture develops to partially replace the steady decrease in wild stocks (Ivy and Giraspy, 2006).

In this study, the status of sea cucumber resources in the existing fishery area in Qeshm Island is assessed and compared with other neighbouring countries, and it also provides management recommendations.

\section{MATERIAL AND METHODS}

Information regarding the status of this Iranian fishery was obtained through a questionnaire developed by the authors of this scientific paper. Information on the species exploited, fishing techniques, processing and trading was obtained through direct field observations and through a questionnaire that was given during interviews with sea cucumber fishers and local authorities around the Qeshm Island. More than 16 people/fishermen answered the questionnaire.

During each field survey, we interviewed fishermen about the length (duration) of their fishing trip, the number of involved fishermen, and the method and location of the collection. We also recorded the number and species of the collected sea cucumbers. In this survey, data were collected from a local fisherman, involved in this activity during 2004-2006, and the selected sampling area was based on the information provided by them. The study area covered the north coast of Qeshm Island $\left(26^{\circ} 58^{\prime} \mathrm{N} 56^{\circ} 14^{\prime} \mathrm{E}\right)$, near Hamon jetty to left port $\left(26^{\circ} 56^{\prime} \mathrm{N} 55^{\circ} 47^{\prime} \mathrm{E}\right)$ at $20-25 \mathrm{~m}$ from the coast line, where the water depth was 5-12 $\mathrm{m}$. Sampling was carried out in two seasons (summer and autumn of 2010) (Fig. 1).

Sea cucumbers were harvested by scuba diving. According to the information from the fishermen, this species was caught in 15-18 m depth easily. Because this species is nocturnal (James, 2001), during the day they are under the sand so they are not visible. Due to the turbidity in these areas, hand spraying method was used for fishing. As such, the diver moved his palms over the sediments bed to touch, extract and collect the sea cucumber. This method requires experienced divers to decry the risk and dangers. Fishing operations have been done sporadically during the day until sunset. The individuals were caught and brought to the surface immediately to reduce stress and prevent them from leaving the internal organs as a defensive mechanism; they were put into sea water tanks. 


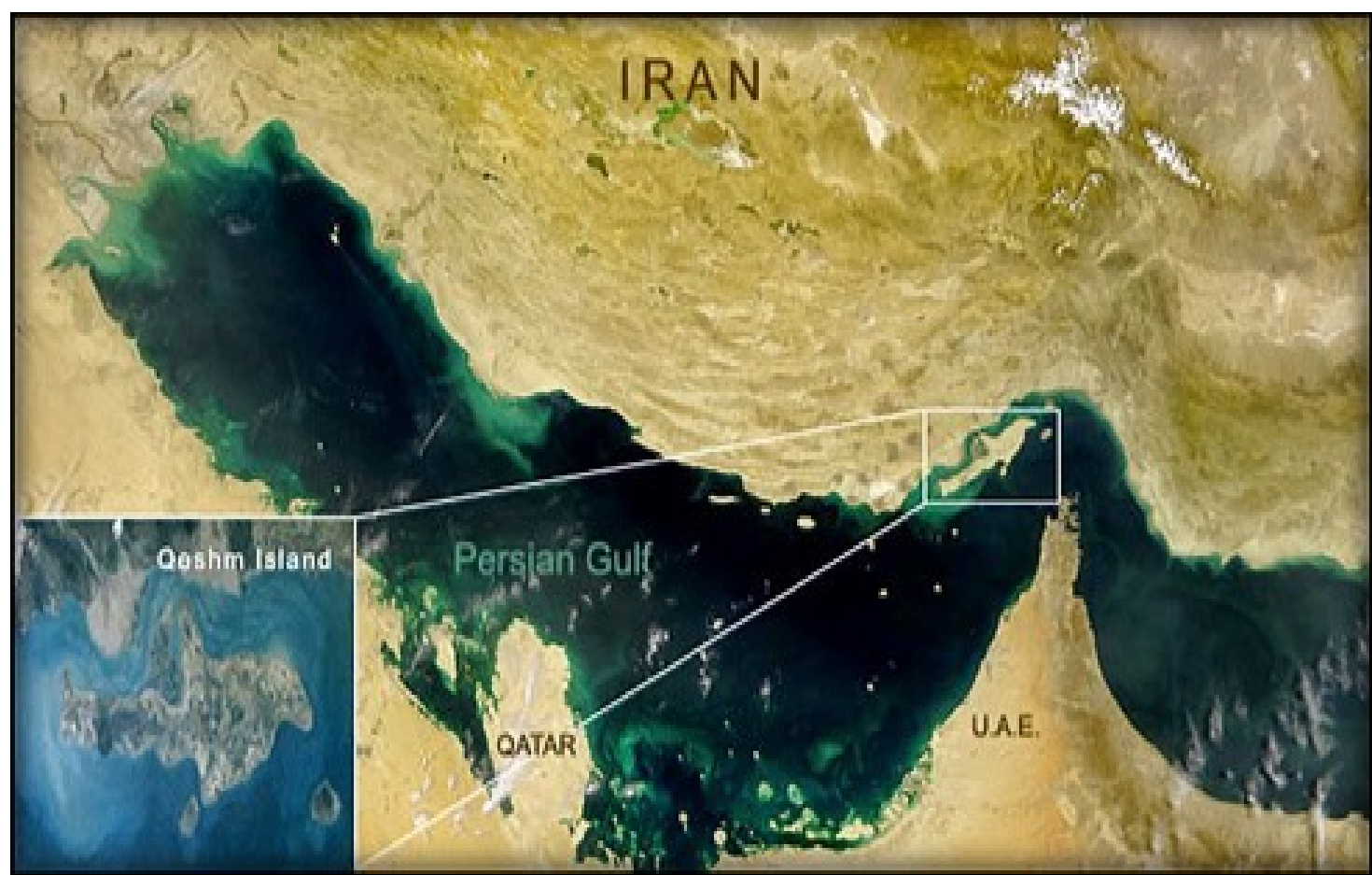

Figure 1: Position of sampling site of Holothuria scabra in the Persian Gulf, Qeshm Island area.

\section{RESULTS AND DISCUSSIONS}

Sea cucumber fishing in Qeshm Island area began in 2004, based on the current demand in Qeshm Island from Indian and Bangladesh traders. Exploitation of this species has been high during 2004-2006 in Iran, especially in Qeshm Island. Fishing operations by local fishermen have taken place in recent years based on current demand in Qeshm Island from Indian and Bangladesh traders.

During these years, around 5-6 diving groups, (each group contained at least 4-5 experienced divers) with the diving mask technique, tried to harvest sea cucumbers. Qeshm Island fishing operation was performed only by men, but throughout many parts of the world women have a significant role in fishing and collecting sea cucumbers (Al-Rashdi et al., 2007). This group of samples have been delivered completely fresh to those foreign nationals illegally, at 3000-4000 RLS per one sea cucumber in 2004. However, the cost in 2006 has been 10000-9000 RLS per piece. They processed the sea cucumber producing the final product (beche-de-mer) and transported it by air to the UAE and then transferred it from there to international markets. There were seven main Holothuria scabra fishing grounds in Qeshm Island: Hamoon, Kovei, Hormoz, Tolla, Ramchah, Messen and Hengam (Fig. 2).

The estimated number of fishermen was 150-200 in 2004-2006, indicating an increase in demand for beche-de-mer and resulting in a high income for the fishers and traders. The average fishing hours per fisher per working day were five to six hours with an average collection of 150-200 live sandfish per fishing trip. Men involved in this fishery perform a $100 \%$ of other income-generating activities. 
Table 1: Comparison of sea cucumber fishery indicators between sultanates of Oman and Iran (2004-2008).

\begin{tabular}{|c|c|c|c|}
\hline $\begin{array}{l}2004-2005 \\
\quad \text { (Iran) }\end{array}$ & $\begin{array}{c}2007-2008 \\
\text { (Oman) }\end{array}$ & $\begin{array}{c}2004-2005 \\
\text { (Oman) }\end{array}$ & Indicator \\
\hline Targeted size & $>25 \mathrm{~cm}$ & $\begin{array}{l}\text { All sizes (including } \\
<15 \mathrm{~cm} \text { ) }\end{array}$ & $>20 \mathrm{~cm}$ \\
\hline CPUE (ind. $\mathrm{h}^{-1}$ ) & 25 ind. $^{-1}$ & $<5$ ind. $\mathrm{h}^{-1}$ & $>30$ ind. $^{-1}$ \\
\hline $\begin{array}{l}\text { Price to fisher } \\
\text { (Iranian rials) }\end{array}$ & $3000-7000$ & $35000-50000$ & $4000-9000$ \\
\hline Targeted species & Holothuria scabra & $\begin{array}{l}\text { Holothuria scabra, } \\
\text { Holothuria atra and } \\
\text { Holothuria lecospilata }\end{array}$ & Holothuria scabra \\
\hline Fishing grounds & $\begin{array}{l}6 \text { recorded in Mahut } \\
\text { Bay }\end{array}$ & $\begin{array}{l}7 \text { recorded grounds in } \\
\text { Mahut Bay plus } 2 \\
\text { recorded in Marish } \\
\text { strait }\end{array}$ & $\begin{array}{l}7 \text { recorded in Qeshm } \\
\text { Island }\end{array}$ \\
\hline $\begin{array}{ll}\% \text { of women and } \\
\text { children }\end{array}$ & $50 \%$ & $15 \%$ & $100 \%$ \\
\hline Fishing methods & $\begin{array}{l}\text { Low tide collection by } \\
\text { hand }\end{array}$ & $\begin{array}{l}\text { Low tide collection by } \\
\text { hand }(70 \%) \text { skin - } \\
\text { diving }(30 \%)\end{array}$ & Skin - diving (100\%) \\
\hline
\end{tabular}

\section{Exploited siles for Holothuria scabra fishery in lran}

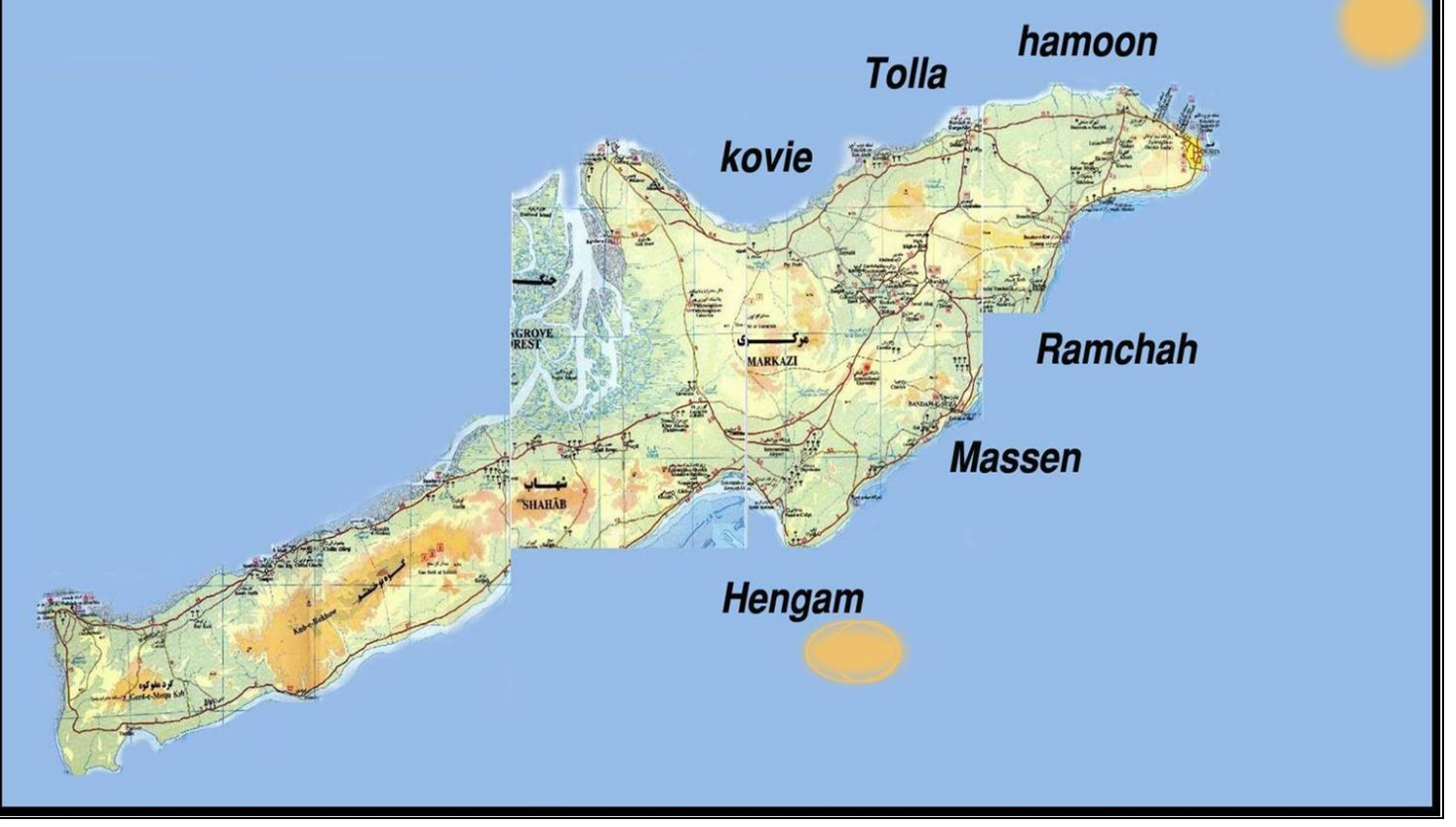

Figure 2: Exploited sites for Holothuria scabra fishery in the Persian Gulf,

Qeshm Island area. 
Qeshm Island, which is in the north coast of the Persian Gulf, is the main area of sea cucumber harvesting in Iran. All the processing expenditures for the fishery in Qeshm Island (gutting, first cooking, preserving and storing, cleaning, second cooking, first drying and second drying) were done by the traders.

Customs inspectors at the border check post (airport) are unfamiliar with or do not recognize sea cucumbers, especially the dried ones, and so the product passes through the border without identification. Fortunately, given proper management practices and timely cooperation with the Hormozgan Fisheries Department, Qeshm Free Zone Organization, the International Qeshm Airport and Foreign Nationals Department are to deal with illegal fishing, the demand for this product is worth less, so the local fishing operations were stopped from 2006. To achieve its real protected species status, efforts should be done to prevent overexploitation.

Holothuria scabra is an aspidochirote holothurian widely distributed in coastal regions throughout the Indo-Pacific region (Conand, 1997). Holothuria scabra is often found on the inner reef flats and near estuaries, half buried in the silt sand during the day and emerging at night to feed (Mercier et al., 1999). Holothuria scabra is among approximately 20 aspidochirote species that constitute the beche-de-mer fishery in the Indo-Pacific and is among the most valuable species for trade (Conand and Byrne, 1993). Because this fishery is quite recent, there are currently no traditional or state-directed management strategies in place (i.e. it is a fully open access fishery) (Charles, 2001).

Although Holothuroidea have been exploited for at least 1,000 years in India, Indonesia and Philippines (Conand, 2004), their exploitation in Iran is recent. Because of the illegal activities of fishermen and traders in Qeshm Island accurate information regarding the amount of fishing does not exist for the years 2004-2006, so the value of this species is unknown, while in the rest of the world beche-de-mer production is revenue industry.

Six fishing regions have been reported in Mahout Bay in the Sultanate of Oman (AlRashdi et al., 2007), while the Qeshm Island has seven areas in the north and south that are known by fishermen.

Al-Rashdi et al. (2005) reported the most active sea cucumber fishing activities occurs in the spring low tide by walking in the Oman coast. During 2007-2008, about 30 percent of fishermen used the diving mask technique for deeper depths; also reported was the fact that about $50 \%$ of the local women and children of fishermen collected sea cucumbers, while in 2007-2008 this rate dropped to about 10\%. But, in this study was observed that the hunting and fishing operations in the area of Qeshm Island were done only by men. Al-Rashdi and colleagues during 2005 to 2008 showed that due to excessive exploitation of natural reserves of Holothuria scabra species, their density was reduced in Oman coast. The size of the target of $25 \mathrm{~cm}$ in 2004-2005 was reduced to $15 \mathrm{~cm}$ in 2007-2008. Due to the sharp decline of this species reserve, fishermen started looking for other species that have less commercial value, and that are exploited.

Most exploited sea cucumber populations around the world experience similar declines at the onset of commercial exploitation (Conand, 1997; Uthicke and Conand, 2005). The frequency of Holothuria scabra reported in Qeshm Island $(24.86 \pm 3.58 \mathrm{~cm})$ has a similar situation in areas where it's not exploited in the Red Sea (Hassan, 2005) and Mahout Bay in Oman in 2005 (Al-Rashdi et al., 2007). So, it seems that the area of Qeshm Island has adequate reserves and similar areas in other highly ecosystem and nearly unexploited sea cucumber population. 


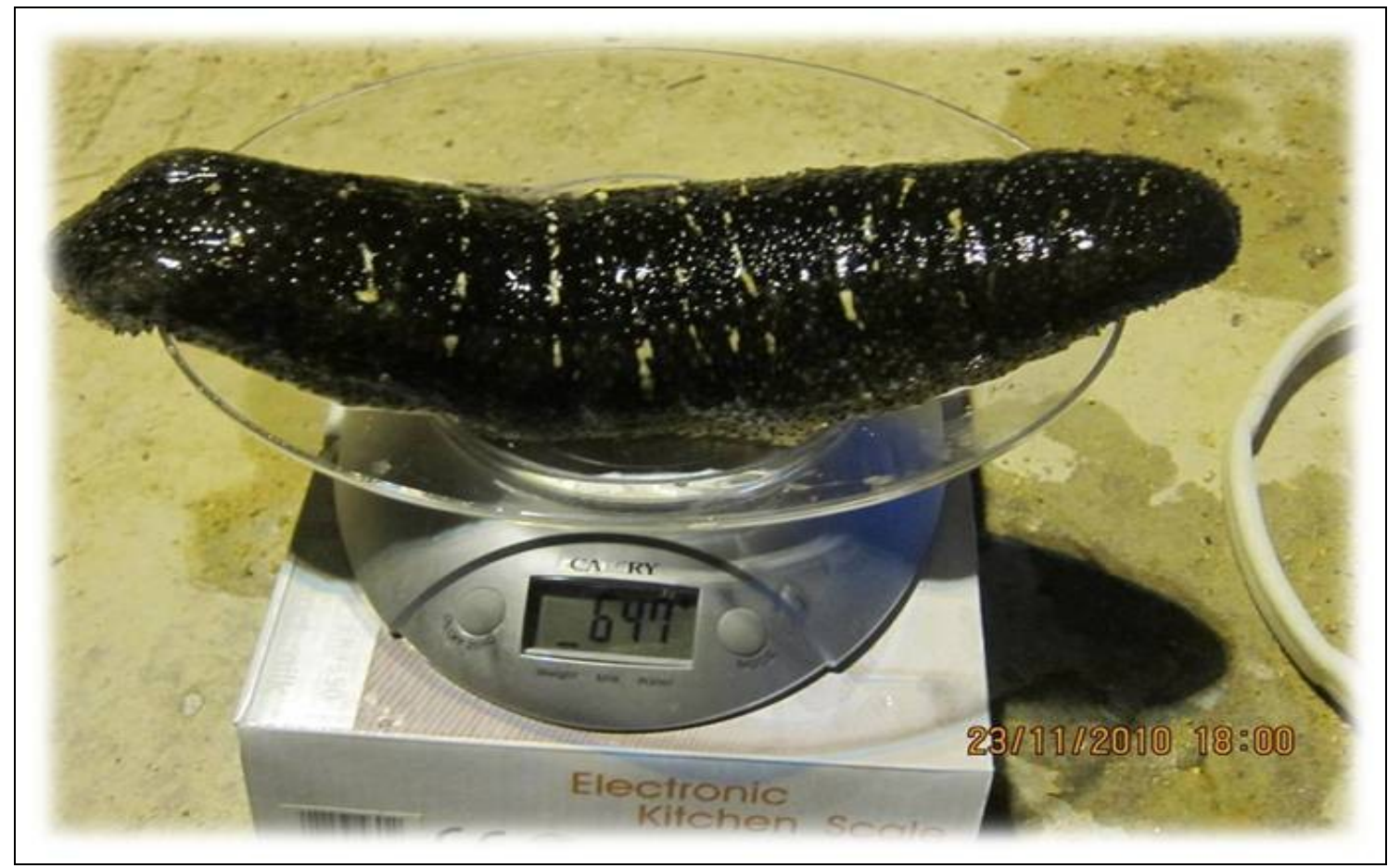

Figure 3: Holothuria scabra observed in Qeshm Island.

The average sizes of harvested species in Qeshm Island show that there is an optimal level of stockpiles and higher than first maturity (equivalent to $18-16 \mathrm{~cm}$ for the species Holothuria scabra) reported by (Conand, 1989; Kithakeni and Ndaro, 2002; Hassan, 2005). However, the smaller size individuals fetch have a much lower price than the larger ones, more sea cucumbers needed to be caught. This, in turn, led to the collection of immature individuals (Richmond, 1996). But in Qeshm Island where Holothuria scabra was exploited, it seems there are ideal reserves situations in this region. The recent addition of low-value species (Holothuria atra and Holothuria leucospilota) to catches indicates the poor status of the fishery in Mahout Bay (Friedman et al., 2008).

These soon-to-be implemented regulations and several closure experiments in the Indo-Pacific have shown that overfished sea cucumber stocks were slow to recover. This is partially because holothurians are broadcast spanners, whose fertilization rate drops rapidly at low population densities. Modelling experiments indicate that individuals separated by only a few meters do not contribute practically to larvae production because of the dilution of sperm in the water column (Claereboudt, 1999).

The high demand for beche-de-mer in Asia and the systematic overexploitation of wild populations support the call for sea cucumber farming. Aquaculture is a potential alternative source for the market and can also sustain wild harvest fisheries. Over the past decade, efforts to develop hatchery techniques for the culture of commercially important sea cucumber species have increased significantly (James et al., 1994; James, 1996a; Ramofafia et al., 1995; Ito, 1995; Asha and Muthiah, 2002; Lovatelli et al., 2004; Giraspy and Ivy, 2005).

Sea ranching of sea cucumbers has become very popular in the recent years. Results suggest that the substrata of the seeding area play an important role in the survival of the released juveniles, as they need protection from predators and require an abundant natural food (Jiaxin, 2003). 
From the above description of the situation of the sea cucumber fishery in Qeshm Island, several management suggestions have been identified in this study:

1 - research projects are needed on evaluation of existing resources to identify species, density and distribution of sea cucumber species, especially in the Persian Gulf Coast of Qeshm Island;

2 - research projects on ecological studies, biological, rebuild stocks, to make certain reproductive biology and to certainly identify the size of first maturity;

3 - continue the ban on fishing until the determination of the stock assessment;

4 - harvest only to provide brood stock for hatchery centre;

5 - planning for commercial production of larvae for culture and sea ranching projects;

6 - capacity building programmers - training, study tours, participation in national and international meetings and workshops on sea cucumbers, should be conducted and supported by government organizations;

7 - protection of natural habitats such as Qeshm Island to supply broodstock of Holothuria scabra species in the country.

\section{REFERENCES}

1. Alexandra S., Silchenko S., Avilov A., Alexander S., Antonov S., Anatoly I., Kalinovsky P., Dmitrenok S., Vladimir I., Kalinin V., Stonik A., Woodward C. and Collin P. D., $2005-$ Glycosides from the sea cucumber Cucumaria frondosa. III. Structure of frondosides A2-1, A22, A2-3, and A2-6, four new minor monosulfated triterpene glycosides, Canadian Journal of Chemistry, 83, 21-27.

2. Al-Rashdi K. M., Al-Busaidi S. S. and Al-Rassadi I. H., 2007a - Status of the sea cucumber fishery in the Sultanate of Oman, SPC Beche de mer Information Bulletin, 25, 17-21.

3. Al-Rashdi K. M., Claereboudt M. R. and Al-Busaidi S. S., 2007b - Density and size distribution of the sea cucumber, Holothuria scabra (Jaeger, 1935), at six exploited sites in Mahout Bay, Sultanate of Oman, Agricultural and Marine Sciences, 12, 43-51.

4. Asha P. S. and Muthiah P., 2002 - Spawning and larval rearing of sea cucumber Holothuria (Theelothuria) spinifera Theel, SPC Beche-de-Mer Information Bulletin, 16, 11-15.

5. Brooke Y. and Shannon R., 2004 - Ecological assessment of the developmental Moreton Bay beche-de-mer fishery. A report to Environment Australia on the ecologically sustainable management of a highly selective dive fishery, 25 .

6. Charles A. T., 2001 - Sustainable fishery systems, Blackwell Science, Oxford, 370.

7. Claereboudt M. R., 1999 - Fertilization success in spatially distributed populations of benthic Free-spawners: a simulation model, Ecological Modelling, 121, 221-233.

8. Conand C., 1990 - The fishery resources of Pacific Island countries, part 2, Holothurians, FAO Fisheries Technical Paper, 142.

9. Conand C., 1997 - Are holothurians fisheries for export sustainable? International Congress of Reefs, Panama, 2: 2021-2026.

10. Conand C., 1998 - Holothurians, in: Carpenter K. and Niem V. (eds), FAO species identification guide, The marine living resources of the Western Central Pacifici, 2, cephalopods, crustaceans, holothurians and sharks, 1157-1190.

11. Conand C., 2004 - Present status of world sea cucumber resources and utilization: An international overview, 13-23, in: Lovatelli A., Conand C., Purcell S., Uthicke S., Hamel J.-F. and Mercier A. (eds), Advances in sea cucumber aquaculture and management, FAO Fisheries Technical Paper, Geneva, D’Silva D., 2001, The Torres Strait beche-de-mer (sea cucumber) fishery, Beche-de-Mer Information Bulletin, 15, 2-4. 
12. Conand C., 2006 - Sea cucumber biology: taxonomy, distribution, biology, conservation status, 33-50, in: The Proceedings of the CITES workshop on the conservation of sea cucumbers in the families Holothuriidae and Stichopodidae, Bruckner A. W. (ed.). OAA Technical Memorandum, 244.

13. Conand C. and Byrne M., 1993 - A review of recent developments in the world sea cucumber fisheries, Marine Fisheries Review, 55, 1-13.

14. FAO, 2006 - Sandfish hatchery techniques, by Natacha Agudo.

15. Friedman K., Purcell S. W., Bell J. D. and Hair C., 2008 - Sea cucumber fisheries: A manager's toolbox, Australian Government, Australian Centre for International Agricultural Research, Canberra, Australia, 32.

16. Giraspy D. A. B. and Ivy W., 2005 - Australia's first commercial sea cucumber culture and sea ranching project in Hervey Bay, Queensland, Australia, SPC Beche-de-Mer Information Bulletin, 21, 29-31.

17. Grisilda I. and Giraspy D. A. B., 2006 - Development of large-scale hatchery production techniques for the commercially important sea cucumber Holothuria scabra var. versicolor (Conand, 1986) in Queensland, Australia, SPC Beche-de-mer Information Bulletin, 24.

18. Hasan M. H., 2005 - Destruction of a Holothuria scabra population by overfishing at Abu Hamada Island in the Red Sea, Marine Environmental Research, 60, 499-511.

19. James D. B., Gandhi A. D., Palaniswamy N. and Rodrigo J. X., 1994 - Hatchery techniques and culture of the sea cucumber Holothuria scabra, CMFRI (Central Marine Fisheries Research Institute, Cochin, India) special publication, 57, 120-126.

20. James D. B., 1996 - Culture of sea cucumber, in: Rengarajan K. (ed.), Artificial reefs and sea farming technologies, Bulletin of the Central Marine Fisheries Research Institute, 48, 120-126.

21. James D. B., 2001 - Twenty sea cucumbers from seas around India, Naga, ICLARM Quart., 24, 4-8.

22. Jiaxin C., 2003 - Overview of sea cucumber farming and sea ranching practices in China, SPC Beche-de-Mer Information Bulletin, 18, 18-23.

23. Kithakeni T. and Ndaro S. G. M., 2002 - Some aspects of the sea cucumber, Holothuria scabra (Jaeger, 1935), along the coast of Dar-es-Salaam, Western Indian Ocean Journal of Marine Science, 1, 163-168.

24. Lovatelli A., Conand C., Purcell S., Uthicke S., Hamel J.-F. and Mercier A. (eds), $2004-$ Advances in sea cucumber aquaculture and management, FAO Fisheries Technical Paper, 463, Rome: FAO, 425.

25. Lto S., 1995 - Studies on the technological development of the mass production for sea cucumber juvenile, Stichopus japonicas, Saga Prefectural Sea Farming Center, Japan, 87.

26. Mamelona J., Pelletier E., Girard-Lalancette K., Legault J., Karboune S. and Kermasha S., 2007 - Quantification of phenolic contents and antioxidant capacity of Atlantic sea cucumber, Cucumaria frondosa, Food Chemistry, 104, 1040-7.

27. Mercier A., Battaglene S. C. and Hamel J.-F. 1999 - Daily burrowing cycle and feeding activity of juvenile sea Cucumbers Holothuria scabra in response to environmental factors, Journal of Experimental Marine Biology and Ecology, 239(1), 125-156.

28. Ramofafia C., Gervis M. and Bell J. 1995 - Spawning and early larval rearing of Holothuria atra, SPC Beche-de-Mer Information Bulletin, 7, 2-6.

29. Richmond R. H., 1996 - Introduction and overview's, 2-6, in: Richmond R. H. (ed.), Suggestions for the management of sea cucumber resources in Micronesia, Results of the Workshop, A regional Management Sustainable Sea Cucumber Fishery for Micronesia, University of Guam Marine Laboratory, Technical Report, 101, 75.

30. Thomas J. D. and Hatrel L. W. 1997 - Characterizations of the Anglicans of the toxic principle of the sea cucumber Holothuria atra, Toxicom, 15, 461-462.

31. Uthicke S. and Conand C. 2005 - Local examples of beche-de-mer overfishing: an initial summary and request for information, SPC Beche-de-mer Information Bulletin, 21, 9-14. 